\begin{tabular}{|l|l|l|l|l|l|} 
J. Tek. Ling & Vol.11 & No.3 & Hal. 401 - 407 & Jakarta, September 2010 & ISSN 1441-318X \\
\hline
\end{tabular}

\title{
PERUBAHAN TUTUPAN LAHAN DAN LINGKUNGAN: AKUNTING SUMBERDAYA ALAM PROPINSI KALIMANTAN SELATAN
}

\author{
Rony M. Bishry \\ Peneliti Pada Pusat Teknologi Inventarisasi Sumberdaya Alam \\ Badan Pengkajian dan Penerapan Teknologi
}

\begin{abstract}
The natural resources utilization for economic development has became the driver of land cover and and environmental change. The policy of natural resources utilization for development in Kalimantan Selatan has changed the net value of its natural resource capital. For Kalimantan Selatan Province it is recorded that between the year of $2004-2007$, the economic value of its natural resources has changed as much as Rp. 621,9 billion.

However comparing to the need of annual budget to treat the critical land amounting to $R p 555,9$ billion and the depreciation of its roads amounting to the Rp. 1 Trillion, the net value of its natural resources capital is relatively small.
\end{abstract}

Key Word: natural resources and environment, regional development

\section{PENDAHULUAN}

\subsection{Latar Belakang}

Perekonomian Kalimantan Selatan didukung oleh ketersediaan sumberdaya alam diantaranya batubara, pertanian, rawa, dan hutan. Penggunaan sumberdaya alam untuk kegiatan ekonomi dapat merubah nilai ekonomi total dari modal sumberdaya alam dan lingkungan.

Sektor pertanian serta sektor pertambangan dan penggalian sampai tahun 2007 masih merupakan sektor yang paling dominan dalam pembentukan PDRB. Kontribusi sektor pertanian pada tahun 2007 sedikit mengalami kenaikan dibandingkan tahun sebelumnya. Pada tahun 2007, kontribusi sektor pertanian terhadap perekonomian Kalimantan Selatan sebesar 22,46 persen atau sedikit mengalami kenaikan dibanding tahun sebelumnya 22,43 persen. ${ }^{1)}$
Kontribusi sektor pertambangan dan penggalian pada tahun 2007 meskipun masih besar mengalami penurunan yaitu sebesar 21,70 persen dibanding tahun 2006 yang mencapai sebesar 21,86 persen. Sedangkan untuk nilai ekspor Kalimantan Selatan tahun 2005, batubara merupakan penyumbang terbesar mencapai $71,4 \%$ dari total nilai ekspor Kalimantan Selatan sebesar US \$1.208.774.000.

Kontribusi subsektor kehutanan terhadap PDRB memiliki kecenderungan menurun dari tahun ke tahun. Pada tahun 2002 nilai total kontribusinya $1,53 \%$, turun menjadi $1,46 \%$ pada tahun 2003 , dan 1,40 $\%$ tahun 2004. (BPS, 2004). ${ }^{2)}$

Untuk memperkirakan jumlah produksi pertanian dari daerah rawa digunakan asumsi bahwa setiap komoditas pertanian (pangan, holtikultura, perikanan, dan peternakan) 
yang berasal dari kabupaten yang memiliki kawasan rawa, maka hasil pertaniannya berasal dari rawa.

Pemanfaatan sumberdaya alam tersebut diwarnai dengan ekses yang merugikan, termasuk kerusakan lingkungan hidup dan penurunan nilai ekonomi total modal SDA. Ekses negatif lain yang terlihat nyata adalah dampak yang ditimbulkan oleh transportasi untuk batubara di sekitar Banjarmasin.

Dari aspek kondisi geografis, Provinsi Kalimantan Selatan terletak pada 49,2" - $116^{\circ} 32^{\prime} 43,4^{\prime \prime}$ Bujur Timur dan $1^{\circ} 2^{\prime}$ ' 47,88" - 4 56' 31,56" Lintang Selatan. Kemudian berdasarkan konstelasi hubungan antar wilayah, provinsi ini berada di posisi sentral diantara kepulauan Nusantara yang menjadikan wilayahnya sangat terbuka dan merupakan jalur arus barang, jasa serta mobilitas sosial yang tinggi, terutama ke pulau Jawa, Sulawesi dan Bali, bahkan ke beberapa negara lain, khususnya di kawasan Asia Pasifik. Sebagai salah satu pintu gerbang dari pulau Jawa, Kalimantan Selatan juga menjadi transit arus barang dan jasa dari dan ke Provinsi Kalimantan Timur serta Kalimantan Tengah.

\subsection{Tujuan}

\section{Tujuan pengkajian ini adalah:}

- Menganalisa dampak penggunaan sumberdaya alam dengan akunting SDA dan lingkungan dengan melihat nilai neto ekonomi total modal SDA dan lingkungan.

- Menganalisa sumberdaya alam sebagai elemen inti dalam pengembangan daerah.

\section{KERANGKA PIKIR}

Pada setiap penggunaan SDA sudah barang tentu akan terjadi perubahan tutupan Iahan. Perubahan yang terjadi identik dengan perubahan nilai ekonomi lahan dan dampak yang menimbulkan serangkaian keadaan yang berbeda. Dampak penggunaan SDA yang terjadi akan diukur dalam kategori perubahan nilai ekonomi neto tutupan lahan dan perubahan lingkungan. Selain itu di sisi lain dapat terjadi dampak negatif penggunaan SDA yang mempengaruhi jejaring transportasi. Perubahan lingkungan berupa degradasi lingkungan dilakukan dengan melihat berapa lahan telantar seperti alang alang yang tercipta disebabkan penggunaan SDA untuk kegiatan ekonomi.

\section{Akunting SDA}

Akunting SDA Indonesia dilakukan oleh Reppetto (1991) dengan data 1970an dan 1980an. ${ }^{3)}$ Perhatian utama pada deplesi SDA sebagai dpepresiasi modal SDA pada perhitungan pendapatan nasional. Akunting SDA Indonesia dibagi atas hutan, minyak, dan tanah.

Reppetto menghawatirkan eksploitasi SDA mineral, hutan dan tanah yang menyebabkan erosi, merusak SDA air, menghabiskan SDA ikan dan lainnya. Pada masa itu SDA memberikan kontribusi sekitar $43 \%$ terhadap pendapatan nasional dan sekitar $83 \%$ dari pendapatan ekspor serta menyerap 55\% tenaga kerja nasional. Kontribusi SDA ternyata diikuti dengan deplesi SDA yang tidak diperhitungkan dalam pendapatan nasional.

Repetto melihat perhitungan pertumbuhan pendapatan nasional yang terlalu tinggi dibandingkan dengan kenyataan jika deplesi SDA dihitung sebagai depresiasi. Repetto melihat adanya angka deplesi yang melebihi investasi bruto yang berarti Indonesia membiayai konsumsi nasional dengan deplesi SDA.

Sejauh ini belum ada lagi penelitian lengkap akunting sumberdaya untuk Indonesia. Akunting SDA dalam penelitian ini adalah untuk menghitung nilai ekonomi neto SDA dengan rumus valuasi sebagai berikut: 
$T E V=(D U V+I U V+O V)+(X V+B V)$ Dimana:

TEV adalah Nilai ekonomi neto SDA DUV adalah Nilai guna SDA

IUV adalah Nilai non guna SDA

OV adalah Nilai opsi

XV adalah Nilai keberadaan

BV adalah Nilai waris berikut:

Untuk nilai guna SDA adalah sebagai

$$
R \mathbf{n}=(\mathbf{P t}-\mathbf{C t})
$$

Dimana:

$$
\begin{array}{ll}
\mathbf{R n} & \text { adalah Nilai guna SDA } \\
\mathbf{P t} & \text { adalah Harga pasar per unit produk } \\
& \text { SDA } \\
\mathbf{C t} \quad \begin{array}{l}
\text { adalah biaya-biaya yang dikeluarkan } \\
\text { untuk menghasilkan per unit produk }
\end{array} \\
\text { SDA. }
\end{array}
$$

\section{PENGGUNAAN SDA, PERUBAHAN TUTUPAN LAHAN DAN LINGKUNGAN}

\subsection{Penggunaan Sumberdaya Alam}

Penggunaan sumberdaya alam akan difokuskan pada perkebunan, pertambangan, hutan dan rawa. Selanjutnya pada Tabel 1 dan Tabel 2 akan diperlihatkan Luas lahan sumberdaya alam tahun 2004 dan tahun 2007. Analisa akan dilakukan untuk perkebunan, kehutanan, pertambangan, dan rawa. Perubahan lahan terjadi terutama karena semakin luasnya daerah pertambangan dan perkebunan.

Tabel 1. Luas Sumberdaya Alam Kalimantan Selatan Tahun 2004

\begin{tabular}{|l|l|}
\hline \multicolumn{1}{|c|}{ SDA 2004 } & \multicolumn{1}{c|}{ HEKTAR } \\
\hline Hutan & $1.203 .960,56$ \\
\hline Perkebunan & $305.792,40$ \\
\hline Pertambangan & $4.978,54$ \\
\hline Rawa & $233.377,80$ \\
\hline Areal Penggunaan Lain & $2.014 .899,56$ \\
\hline TOTAL & $3.763 .006,02$ \\
\hline
\end{tabular}

Sumber: Suwargana, et.al., $2008{ }^{4)}$
Tabel 2. Luas Sumberdaya Alam Kalimantan Selatan Tahun 2007

\begin{tabular}{|l|l|}
\hline \multicolumn{1}{|c|}{ SDA 2007 } & \multicolumn{1}{c|}{ HEKTAR } \\
\hline Hutan & $1.193 .939,21$ \\
\hline Perkebunan & $401.175,20$ \\
\hline Pertambangan & $56.140,00$ \\
\hline Rawa & $150.193,20$ \\
\hline $\begin{array}{l}\text { Areal Penggunaan } \\
\text { Lain }\end{array}$ & $1.801 .447,86$ \\
\hline TOTAL & $3.748 .853,19$ \\
\hline
\end{tabular}

Sumber: Suwargana, et.al., $2008^{4)}$

Dari tabel 1 dan 2, terjadi penurunan pada luas hutan, rawa, dan areal penggunaan lain. Sedangkan untuk luas perkebunan dan pertambangan terjadi peningkatan.

\section{1) Perkebunan}

Perkebunan di Kalimantan Selatan terdiri dari dua jenis yaitu:

- perkebunan besar (swasta dan negara)

- perkebunan rakyat

Kedua jenis perkebunan ini mempunyai karakteristik yang sangat berbeda, baik dalam sistem pengelolaan perkebunan maupun pengolahan produk. Renstra Dinas Perkebunan Propinsi Kalimantan Selatan menyebutkan luasan perkebunan yang ada pada tahun 2003 kurang lebih 397.739 ha dengan klasifikasi sebagai berikut :

- perkebunan rakyat $235.343 \mathrm{Ha}$

- perkebunan besar swasta (PBS) $154.217 \mathrm{Ha}$

- perkebunan besar negara (PBN) $8.179 \mathrm{Ha}$

Komponen perkebunan rakyat merupakan komponen terbesar di antara komponen lain pada tahun 2003. Kebun rakyat didominasi karet. Perkebunan karet rakyat banyak yang sudah tua tapi tidak ada peremajaan sehingga kebun rakyat 
menurun pada tahun 2005. Kebun swasta meningkat pada tahun 2005 dengan adanya penambahan pada kebun sawit. Kebun sawit semakin dominan dan untuk perhitungan nilai ekonomi perkebunan akan digunakan data kebun sawit. ${ }^{5}$

Tabel 3. Perkembangan Luas Kebun di Provinsi Kalimantan Selatan

\begin{tabular}{|l|l|l|l|}
\hline & \multicolumn{3}{|c|}{ Tabel } \\
\hline Kebun & RAKYAT & BUMN & SWASTA \\
\hline 2005 & 161.629 & 8703 & 283.138 \\
\hline 2003 & 232.105 & 8179 & 151.387 \\
\hline
\end{tabular}

Sumber: KALSEL dalam Statistik 2007

Dari data tutupan lahan pada tahun 2004 perkebunan adalah seluas 305.792,49 ha dan meningkat menjadi $401.175,20$ ha pada tahun 2007. Pembukaan perkebunan diperkirakan telah merubah tutupan lahan dari hutan menjadi perkebunan. Jumlah ini jauh lebih rendah daripada yang tercatat pada perencanaan pemerintah daerah. Peningkatan sekitar 95.000 ha perkebunan hampir sama dibandingkan dengan pembukaan hutan.

\section{2) Kehutanan}

Kawasan Hutan Kalimantan Selatan menurut fungsinya berdasarkan Perda Propinsi Kalimantan Selatan No.9 Tahun 2006, adalah seperti pada Tabel di bawah ini.

Tabel 4. Kawasan Hutan menurut Fungsi di Propinsi Kalimantan Selatan

\begin{tabular}{|l|l|l|l|}
\hline No & \multicolumn{1}{|c|}{ Fungsi } & Luas (ha) & $\begin{array}{c}\text { \% terhadap } \\
\text { Wilayah Kalsel } \\
\mathbf{3 . 7 5 2 . 0 5 2} \text { ha }\end{array}$ \\
\hline 1 & HL & 751.252 & 20,02 \\
\hline 2 & HP Terbatas & 212.177 & 5,65 \\
\hline 3 & HP Tetap & 627.672 & 16,72 \\
\hline 4 & HP Konversi & 67.902 & 1,80 \\
\hline & Total & 1.659 .003 & 44,19 \\
\hline
\end{tabular}

Sumber : Pemanfaatan Hutan dan Hasil Hutan (2005)
Dari data tutupan Lahan hutan pada tahun 2004 adalah seluas 1.203.960.56 ha dan menurun menjadi 1.193.939,21 ha pada tahun 2007. Penurunan terjadi dengan peningkatan luas perkebunan yang diperkirakan adanya perubahan dari luas hutan. Terjadi pula penurunan produksi kayu dan meskipun luas area pengambilan kayu meningkat. Diperkirakan kualitas hutan yang ada menurun pula.

\section{3) Pertambangan}

Propinsi Kalimantan Selatan memiliki potensi batubara yang cukup besar dengan kualitas yang baik. Sebaran potensi batubara tersebar hampir di seluruh kabupaten. Batubara sangat dominan, sehingga untuk perhitungan ekonomi pertambangan digunakan nilai ekonomi batubara.

Pola penyebaran batubara di Kalimantan Selatan menyebar pada batuan yang terbentuk pada zaman Kenozoikum (EosenPleistosen) terdiri atas Formasi Tanjung, Berai, Warukin, Dahor yang merupakan batuan sedimen yang mendominasi hamparan berbentuk perbukitan terletak di sayap barat dan timur Pegunungan Meratus.

Penambangan terus dilakukan dengan orientasi keperluan ekspor sehingga menjadi sumber penerimaan pusat dan daerah. Namun demikian pasca penambangan banyak meninggalkan lahan lingkungan yang tidak sebaik sebelum penambangan. Disamping itu pula kegiatan merusak sarana seperti infrastruktur transportasi.

Dari data tutupan Iahan untuk pertambangan adalah seluas 4.978,54 ha pada tahun 2004 dan meningkat menjadi $56.140,00$ ha pada tahun 2007. Perluasan kawasan pertambangan berarti deplesi sumberdaya alam pertambangan dan meluasnya kawasan pasca tambang yang rusak secara lingkungan. ${ }^{6}$ ) 


\section{Rawa}

Kondisi fisik geografis Kalimantan Selatan sebagian besar adalah dataran dan rawa. Rawa merupakan suatu daerah yang secara fisik selalu mengalami penggenangan air baik secara periodik maupun permanen. Pola kehidupan masyarakat Kalimantan Selatan antara lain dicirikan dengan mata pencaharian bertani secara menetap, tadah hujan atau pola pasang surut. Posisi ini memudahkan untuk transaksi perdagangan yang menggunakan sungai sebagai prasarana perhubungan utama.

Lahan rawa yang ada di Kalimantan Selatan terdiri dari rawa pasang surut dan rawa lebak. Keberadaan rawa pasang surut tersebar di Kabupaten Banjar, Tapin dan Barito Kuala. Sementara untuk rawa lebak tersebar di daerah-daerah pelembahan yang merupakan batas fisik antara lahan basah dan lahan kering di kaki-kaki pegunungan Meratus mengambil transek menuju Sungai Barito. Beberapa pemanfatan yang telah dilakukan oleh masyarakat sekitar rawa lebak, antara lain: pertanian, perikanan, dan peternakan.

Penggunaan rawa untuk perkebunan kering merubah lingkungan sedangkan perubahan untuk perkebunan lahan basah masih sesuai dengan habitat rawa lainnya. Dari data tutupan Lahan Hampir di seluruh kabupaten ada penggunaan rawa untuk perkebunan dan pertanian.

Dari data tutupan lahan, sumberdaya rawa pada tahun 2004 adalah seluas 233.377,80 ha dan menurun menjadi $150.193,20$ ha pada tahun 2007. Mengecilnya kawasan rawa adalah akibat perubahan kawasan rawa menjadi pertanian/perkebunan.

\subsection{Jejaring Transportasi}

Disamping angkutan air, jalan raya di Kalimantan Selatan banyak digunakan untuk truk pembawa hasil tambang dan kayu. Truk besar ini berada di jalan raya bersama-sama dengan kendaraan penumpang. Sekitar $75 \%$ jalan rusak $(500 \mathrm{~km})$ adalah jalan raya yang
Tabel 5. Kondisi Jalan Negara dan Provinsi (km) Tahun 2005

\begin{tabular}{|l|l|l|l|}
\hline $\begin{array}{c}\text { Keadaan } \\
\text { Jalan }\end{array}$ & Negara & Provinsi & \multicolumn{1}{|c|}{ Total } \\
\hline Baik & 234,62 & 475,31 & 609,93 \\
\hline Cukup Baik & 441,57 & 217,52 & 659,09 \\
\hline Rusak & 155,88 & 134,14 & 290,02 \\
\hline $\begin{array}{l}\text { Rusak } \\
\text { Sekali }\end{array}$ & 32,00 & 229,41 & 361,41 \\
\hline Total & 864,07 & 1056,38 & 1920,45 \\
\hline
\end{tabular}

Sumber: Kawasan Pemukiman dan Infrastruktur Umum Provinsi Kalimantan Selatan (2006) ${ }^{7)}$

digunakan oleh angkutan tambang dan kayu.

Banyak jalan dibuka untuk daerah tambang dan pengambilan kayu. Jalan2 baru ini merubah tutupan lahan dari hutan atau perkebunan menjadi jalan baru. Kerusakan lahan tidak saja yang digunakan untuk jalan, tetapi juga beberapa meter dari badan jalan ikut menjadi rusak secara ekosistim. Kalau biaya perbaikan jalan dianggap sebagai depresiasi dari lingkungan, maka nilai depresiasinya adalah sebesar $500.000 \mathrm{~m} \mathrm{x}$ 10 m x Rp. $200.000 / m^{3}=$ Rp. 1 Triliun. ${ }^{8)}$

Untuk memprediksi kebutuhan jejaring transportasi untuk peningkatan produksi tambang, diusulkan penggunaan jalan pertambangan tersendiri dari para pengusaha dan kereta api sehingga tekanan terhadap moda jalan raya berkurang.

\subsection{Perubahan Nilai SDA dan Lingkungan}

Nilai ekonomi hutan adalah nilai ekonomi total sumberdaya alam hutan yang meliputi nilai guna (use value) dan bukan guna (non use value). Nilai ekonomi total hutan yang dijadikan dasar perhitungan adalah nilai ekonomi total hutan hasil kajian Natural Resources Management (NRM) (2002). ${ }^{9)}$ Nilai ekonomi total hutan adalah sebesar Rp. 38.399.400,- per ha/th, yang terdiri dari Rp.20.118.920,- untuk nilai guna langsung, Rp. 16.522.460,- dari nilai guna tidak langsung, dan Rp. 1.758.020,- untuk nilai opsi. Dengan adanya Perubahan (-) 
Tabel 6. Luas Perubahan Sumberdaya Alam Kalimantan Selatan Tahun 2004 2007

\begin{tabular}{|l|l|}
\hline Perubahan 2004 - 2007 & HEKTAR \\
\hline Hutan & $(-) 10.021,35$ \\
\hline Perkebunan & $(+) 95.382,80$ \\
\hline Pertambangan & $(+) 51.169,464$ \\
\hline Rawa & $(-) 73.234,60$ \\
\hline Areal Penggunaan Lain & $(-) 213.451,70$ \\
\hline
\end{tabular}

Sumber: Diolah dari Suwargana, et.al., 2008

$10.021,35$ ha maka ada penurunan nilai ekonomi SDA sebesar Rp. 384,8 milyar

Berdasarkan hasil studi Junaidi (2005), nilai ekonomi perkebunan kelapa sawit per ha selama 25 tahun dengan discount rate $10 \%$ adalah sebesar Rp. 540.851.281,-- atau Rp 21.634.051,- per tahun. Dengan adanya Perubahan (+) 95.382,80 ha maka ada peningkatan nilai ekonomi SDA sebesar Rp. 2,06 Triliun.

Nilai ekonomi batubara, diperoleh dengan mencari nilai sewa bersih (net rent) per ton batubara. Nilai tersebut diperoleh dari selisih harga FOB batubara dikurangi biaya ekstraksi, pengolahan, transportasi dan normal profit. Dengan analisis tersebut diperoleh nilai net rent per ton batubara adalah Rp. Rp.130.476,-. Dengan adanya Perubahan (+) 51.169,46 ha maka ada peningkatan nilai ekonomi SDA sebesar Rp. 6,7 Milyar.

Sumberdaya alam rawa tidak hanya memiliki nilai guna langsung yang memiliki nilai pasar, tetapi juga memilki nilai guna tidak langsung seperti manfaat jasa ekologis. Berdasarkan luasannya jumlah total rawa di Kalimantan Selatan adalah 558.421,2 ha. Dengan menggunakan beberapa asumsi dan metode Benefit Transfer, dapat diketahui nilai ekonomi totalnya per tahun. Nilai ekonomi sda rawa atas dasar nilai guna langsung adalah sebesar Rp.2.153.199,02 rupiah per tahun. Sedangkan atas nilai guna tidak langsung adalah sebesar Rp. 12.141.000,- rupiah per tahun. Nilai bukan pengunaan sebesar Rp. 150.749,-- per tahun. Dengan demikian nilai ekonomi total sumberdaya alam rawa di Kalimantan Selatan adalah sebesar Rp.15.273.097,02 rupiah per tahunnya. Dengan adanya Perubahan (-) $73.234,60$ ha maka ada penurunan nilai ekonomi SDA sebesar Rp. 1,1 Triliun. Total perubahan nilai ekonomi SDA Kalimantan Selatan adalah

- Rp. 384,8 milyar + Rp. $2.060+$

Rp. 6,7 - Rp 1,100 milyar $=(+)$ Rp. 621,9 Milyar .

Namun demikian ada sekitar 15\% (555.983 ha) dari keseluruhan Iahan Kalimantan Selatan adalah lahan kritis. Lebih kurang $50 \%$ dari lahan kritis $(277.991,5)$ diperkirakan deplesi antara tahun 2004-2007. Dari segi biaya kerusakan, diperlukan dana sebesar minimal Rp 6 juta untuk penanaman dan pemeliharaan pohon (kopi, coklat atau jarak pagar) selama 3 tahun pertama atau Rp 2 juta per tahun. Setelah pohon berusia 3 tahun, lahan dapat dianggap tidak kritis lagi. Untuk itu diperlukan dana sebesar Rp 2 juta X 277.991,5) ha= RP. 555.9,- milyar/tahun untuk penanganan lahan kritis.

Dengan membandingkan total perubahan nilai ekonomi SDA sebesar Rp. 621,9 Milyar dengan keperluan dana per tahun untuk penanganan lahan kritis sebesar RP. 555.9,- milyar/tahun dan depresiasi jalan raya sebesar Rp. 1 Triliun, perubahan neto nilai modal SDA kalimantan Selatan sangat kecil sekali.

\section{KESIMPULAN}

Penggunaan Sumberdaya alam telah merubah tutupan lahan. Perubahan terjadi dengan semakin luasnya daerah pertambangan dan perkebunan. Pengambilan kayu dan penggunaan lahan untuk pertambangan sebagian besar mengakibatkan perubahan tutupan lahan hutan menjadi belukar dan lahan kritis.

Total perubahan nilai ekonomi SDA Kalimantan Selatan dari tahun 2004 ke 
tahun 2007 adalah sebesar Rp. 621,9 Milyar. Namun demikian ada sekitar 15\% (555.983 ha) adalah lahan kritis. Dari segi biaya kerusakan, diperlukan dana untuk perbaikan lahan kritis sebesar RP. 555.9,-- milyar/tahun dan depresiasi jalan raya sebesar Rp. 1 Triliun.

Dengan membandingkan total perubahan nilai ekonomi SDA sebesar dengan keperluan dana untuk perbaikan lahan kritis dan depresiasi jalan raya, perubahan neto nilai modal SDA relatif sangat kecil.

\section{DAFTAR PUSTAKA}

1. Biro Pusat Statistik, 2008, KALSEL dalam Statistik 2007.

2. Biro Pusat Statistik, 2004, KALSEL dalam Statistik 2003.

3. Repetto, et.al., 1989, Wasting Assets: Natural Resources in the National Income Accounts, World Resources Institute.
4. Suwargana, Nana dan Joko Santo, 2008. "Updating Informasi Spasial Tutupan Lahan Propinsi Kalimantan Selatan Dengan Menggunakan Citra Landsat-7/ETM+". LAPAN, Jalan LAPAN 70 Pekayon Pasar Rebo Jakarta Timur. PIT MAPIN XVII, Bandung 10-12-2008.

5. Junaidi, 2005, Nilai Ekonomi Perkebunan Kelapa Sawit, Thesis, Program Pascasarjana Lingkungan, Universitas Indonesia

6. Renstra Pertambangan Kalimantan Selatan, Dinas Pertambangan Propinsi Kalimantan Selatan, 2005

7. Kawasan Pemukiman dan Infrastruktur Umum Provinsi Kalimantan Selatan, 2006, Dinas Pekerjaan Umum.

8. Pusat Teknologi Inventarisasi Sumberdaya Alam - BPPT, 2009, Valuasi Ekonomi dan Jejaring Transportasi Kalimantan Selatan.

9. Natural Resources Management, 2002, Presentase Nilai dan Jasa Hutan, 2003. 